Intersections

Canadian Journal of Music

Revue canadienne de musique
Intersections CANADAN TOURAL OO UUSIC

Bálint András Varga. 2013. From Boulanger to Stockhausen:

Interviews and a Memoir. Rochester, NY: University of

Rochester Press. xi, 400 pp. ISBN 978-1-58046-439-0 (cloth)

\title{
Gregory J. Marion
}

Volume 33, numéro 2, 2013

URI : https://id.erudit.org/iderudit/1032703ar

DOI : https://doi.org/10.7202/1032703ar

Aller au sommaire du numéro

Éditeur(s)

Canadian University Music Society / Société de musique des universités canadiennes

ISSN

1911-0146 (imprimé)

1918-512X (numérique)

Découvrir la revue

Citer ce compte rendu

Marion, G. J. (2013). Compte rendu de [Bálint András Varga. 2013. From Boulanger to Stockhausen: Interviews and a Memoir. Rochester, NY: University of Rochester Press. xi, 400 pp. ISBN 978-1-58046-439-0 (cloth)]. Intersections,

33(2), 169-172. https://doi.org/10.7202/1032703ar

Copyright (C Canadian University Music Society / Société de musique des universités canadiennes, 2013
Ce document est protégé par la loi sur le droit d'auteur. L'utilisation des services d’Érudit (y compris la reproduction) est assujettie à sa politique d'utilisation que vous pouvez consulter en ligne.

https://apropos.erudit.org/fr/usagers/politique-dutilisation/ 
works, most of which are now out of print or have never been published. In previous considerations of Willan, the emphasis has been placed on his organ and choral works, while the instrumental genres have not been treated with the same respect. Perhaps in part this oversight was due to published nonorgan instrumental works being mainly pedagogical piano pieces. (Curiously Kinder does not even refer to this facet of Willan's output in the introduction of his chapter entitled "Pedagogical Music.") Kinder's detailed investigation of letters, annotations by Willan himself, and his own observations could assist in future editing of scores and improved band arrangements, such as that for the Royce Hall Suite. The publication and republication of these noteworthy Canadian compositions by Willan that Kinder calls for will be most welcome in the future.

\section{REFERENCES}

Bryant, Giles. 1972. Healey Willan Catalogue. Ottawa: National Library of Canada.

-1982. Healey Willan Catalogue: Supplement. Ottawa: National Library of Canada.

Clarke, F.R.C. 1983. Healey Willan: Life and Music. Toronto: University of Toronto Press.

Keillor, Elaine, ed. 1994. Music for Orchestra II, Ottawa: Canadian Musical Heritage / Le patrimoine musical canadien.

1994. John Weinzweig and His Music: The Radical Romantic of Canada. Metuchen, NJ: Scarecrow.

Elaine KeIllor

Bálint András Varga. 2013. From Boulanger to Stockhausen: Interviews and a Memoir. Rochester, NY: University of Rochester Press. xi, 400 pp. ISBN 978-158046-439-o (cloth).

From Boulanger to Stockhausen is a recent title in the Eastman Studies in Music series, under the senior editorship of Ralph P. Locke. It is also the third book in the Eastman series written by Varga, preceded by his György Kurtág: Three Interviews and Ligeti Homages (2009), and Three Questions for Sixty-Five Composers (2011). ${ }^{1}$ In many regards, From Boulanger to Stockhausen continues where the previous two books leave off, completing the trilogy with an appended memoir extending to one-quarter of this third book's total length. And the memoir, covering both personal and professional aspects of Varga's life, is as touching as it is informative.

All three books spotlight transcriptions of tape-recorded interviews conducted by Varga over the better part of forty-five years. The orientation in From

1 Varga has published several books, the first in the early 1970 . The genesis of each publication has issued from the author's deft ability as an interviewer. Three Questions for Sixty-Five Composers initially appeared in 1986, as 3 kérdés, 82 zeneszerző. Budapest: Zenemükiadó. 
Boulanger to Stockhausen, however, is distinctive in that its tack is much more catholic than in either the 2009 or the 2011 publication: the focused approach in the earlier contributions (chiefly on Kurtág in the one, and on limited questions posed to a range of composers in the other) is replaced by what might best be likened to epistolary exchanges between Varga and a cross-section of luminaries whose connections with the world of music are nothing if not diverse.

Born in Budapest in 1941, Varga began his professional life in broadcasting, serving principally as an English-language translator for Hungarian State Radio but also delivering on-air concert reviews and music reports, and eventually hosting live interviews with Hungarian and visiting foreign musicians (308-09). In 1971 Varga switched careers, becoming a music promoter initially for Editio Musica Budapest, and later for Universal Editions, which precipitated his relocation to Vienna in $1992 .{ }^{2}$

From Boulanger to Stockhausen cannot be approached in the same manner in which one might examine primary source readings: the book is not, per se, a contribution to academic scholarship. Far from identifying a shortcoming, the comment is intended only to position the publication in an appropriate light. Indeed, serious musicians-professionals and otherwise - are apt to find Varga's conversational approach refreshing. Moreover, there are wonderful gems located between the covers, whether it be conductor Ernest Bour's views on promoting new music, central to Varga's complete interview with him in 1978 (68-75); Nadia Boulanger's brief reminiscence concerning her relationship with Stravinsky (193-94); or Alfred Brendel's likening of musical compositions to characters portrayed by professional stage actors (122). Even Neville Marriner's reference to violist Michael Bowie's faculty position at a "remote university in Canada" (83) may well be construed as endearing, not least by those of us who teach at one or the other of the two "remote" institutions once graced by Bowie's presence (the University of Saskatchewan and the University of Alberta).

Comprising the opening and the longest portion of the book, the interviews themselves fall into two broad groups - the nineteen that take on the flair of feature-length expositions, and the thirteen that Varga himself labels "Snippets." In the former group, the interviewees belong to one of six vocational designations: "Composers," "Conductors," "Instrumentalists," "Singers and a Record Producer," "A Teacher," and "Music Administrators." The placement of the various interviews within these designations is alphabetical as opposed to chronological or predicated upon word count; 3 for instance, under the designation "Instrumentalists" the order of the interviews is: Alfred Brendel

2 The memoir comprises an "Introduction" followed by sixteen brief chapters, chronicling Varga's life with telling-if understated-commentary on familial issues, on coming of age in a Hungary under communist rule, on his near-half-century love affair with the tape recorder ("the single most decisive event in my life" [293]), and on his career trajectory. As such, the memoir provides context for the interviews that represent the first three-quarters of the book's length.

3 The sole exception is the interview with both Iván and Ádám Fischer (107-115), which follows the interview with Hans Swarowsky (99-106). Varga indicates that the ordering here is predicated upon the fact that the Fischers were students of Swarowsky. 
(1931-; interviewed 1978), Yehudi Menuhin (1916-99; interviewed 1972), Isaac Stern (1920-2001; interviewed 1977), and Tibor Varga (1921-2003; interviewed 1980). ${ }^{4}$ Bálint Varga provides contextualizing commentary that speaks to date, location, and circumstance behind each interview, the nineteen lengthier ones and the thirteen "snippets" alike; these crucial introductions also establish the tenor of the ensuing interview-or better, the portion of the tape-recorded whole that has made its way into the transcription.

Of two criticisms that might be levelled against the publication, one amounts to a quibble, while the other is more material. On the first count, the principal portion of the book's title is misleading in that neither the Boulanger nor the Stockhausen interview provides much in the way of a frame, there is no discernible chronological or "impact-oriented" ground that would suggest elevating either of these two names over any number of others. Indeed, using the metric of scope alone, substituting Géza Frid and György Ligeti for Boulanger and Stockhausen, respectively, would have proven more tenable.

The second and more substantial of the two criticisms is that it is not always possible to separate Varga's "voice" from that of his interviewees. Undoubtedly there were challenges in defining and presenting appropriate unity throughout the book, among them the fact that the original interviews were conducted in a host of languages (including Hungarian and German) requiring sensitivity not only to content but equally to idiosyncratic turns of phrase when translating the lot into English, and the interviews occurred across a broad swath of time, which must have complicated editorial considerations immeasurably. These concessions notwithstanding, there are occasions when the matter of authenticity emerges, if sotto voce. At the one extreme is the 1972 interview (15-18) with the Czech composer Alois Hába (1893-1973). Aside from the opening contextualizing comments, Varga's questions of Hába, leading or otherwise, are mute, even though Hába's extemporizing extends to nearly four pages. At the other extreme are the rare moments when Varga's comments seem openly agendaoriented, rather than representing the natural consequence of a "give-and-take" exchange. ${ }^{5}$

On balance, however, there is much that is laudable in From Boulanger to Stockhausen. While the bulk of the thirty-two sessions occurred in the 1970s, and several of them have appeared in print elsewhere, the collection attests to Varga's unswerving dedication to the landscape of contemporary Western art music. The focus is largely on those whose careers have been centred in Europe, which, of course, is logical, given the geographical constraints of Varga's own professional life; the slight Hungarian-centric bent, too, needs no apology. If anything, the conjoining of these latter points will enhance the appeal of the book to English-speaking Canadian and American audiences, as names such as Iván and Ádám Fischer, Walter Legge, and Sir Neville Cardus may not be as familiar in North America as they are in Europe. Equally welcome are

4 The violinist Tibor Varga is not related to the book's author.

5 Portions of the first of the two interviews with Ligeti ("Seventieth Birthday Interview, 1993") come to mind in this regard (28-46). 
the many informative footnotes that bolster the overall impact of the publication by bringing to the twenty-first century names that might otherwise have slipped into oblivion many years ago. Be it the Hungarian conductor Ferenc Fricsay (1914-63 [150n10]), the Croatian conductor and composer Lovro von Matačić (1899-1985 [104n9]), the British organist, composer, and choirmaster Boris Ord (1897-1961 [202n4]), these and like references underscore just how rich, how vibrant, and how diverse music's tapestry truly is-and we have Varga to thank for the subtle reminder itself.

Gregory J. Marion

Keith Potter, Kyle Gann, and Pwyll Ap Siôn, eds. 2013. The Ashgate Research Companion to Minimalist and Postminimalist Music. Burlington VT: Ashgate. 458 pp. ISBN 978-1-4724-0278-3 (ebook), ISBN 978-1-4094-3549-5 (cloth). ISBN 978-1-4094-3550-1 (PDF).

The Ashgate Research Companion to Minimalist and Postminimalist Music is the first collected volume of essays on minimalism, correcting a longstanding absence in the published literature on the style. In the volume, editors Keith Potter, Kyle Gann, and Pwyll Ap Siôn have drawn together scholarship that moves beyond "the big four" minimalists-La Monte Young, Terry Riley, Steve Reich, and Philip Glass - and the notion that minimalism is a fundamentally American phenomenon. Between the Companion and the 2007 foundation of the Society for Minimalist Music (at the conferences of which many of these articles first appeared), it seems minimalism has finally earned its due as a field of musicological inquiry, with its own institutions of support and exchange.

Following the notable absence of any collected volumes on minimalism, the titular inclusion of "and postminimalist" comes as a surprise, but essays on the style are indeed crucial to the Companion, with the "post-" taking on a more clearly defined and delimited definition than minimalism itself. While the editors' introduction presents ten technical characteristics of minimalism-such as harmonic stasis, repetition, gradual process, audible structure, metamusic (a surprising inclusion that is left unexplored in the essays), and others-postminimalism gets extensively treated and is more concisely defined. Kyle Gann, for example, focuses on process, quotation, and limitation of materials in postminimalism, and offers a compelling metaphysics in which "the part can stand for the whole" (58), thus creating a sense of hermeneutic intrigue in which a static surface of sound in fact warrants analysis to reveal structural games that produce the prevailing surface texture and harmony. John Richardson and Susanna Välimäki likewise offer a thorough explanation of the "audiovisual impulse" in postminimalist music, primarily through treating postminimalism's suitability to soundtracking storytelling of an "existential and phenomenological disposition" (237).

In contrast, despite the editors' suggestion that minimalism being "allowed to mean anything is not in the best interest of scholarship" (4), it often feels as if 